The Ballad as Song 



\section{The Ballad as Song}

by

Bertrand Harris Bronson

University of California Press

Berkeley and Los Angeles 1969 
University of California Press

Berkeley and Los Angeles, California

University of California Press, Ltd. London, England

Copyright (C) 1969, by

The Regents of the University of California

Standard Book Number: 520-01399-9

Library of Congress Catalog Card Number: 74-84045

Printed in the United States of America

The essays collected in this volume, here listed in order of first appearance, are reprinted with the permission of the original publishers. "Edward, Edward. A Scottish Ballad," from the Southern Folklore Quarterly, Vol. IV, No. I (1940); to which has been added "A Footnote," from the Southern Folklore Quarterly, Vol. IV, No. 3. "Samuel Hall's Family Tree," from the California Folklore Quarterly, Vol. I, No. I (1942). "The Interdependence of Ballad Tunes and Texts," from the California Folklore Quarterly, Vol. III, No. 3 (1944). "Mrs. Brown and the Ballad," from the California Folklore Quarterly, Vol. IV, No. 2 (I945). "Folk-Song and the Modes," from the Musical Quarterly, Vol. XXXII (1946). "Habits of the Ballad as Song," from Five Gayley Lectures, 1947-1954 (University of California Publications: English Studies, No. 1o [1954]. "On the Union of Words and Music in the 'Child' Ballads," from Western Folklore, Vol. XI, No. 4 (1952). "Two Reviews: George Pullen Jackson and the Shaped-Note Spirituals," the first from the California Folklore Quarterly, Vol. III, No. 4 (1944); and the second from Western Folklore, Vol. XIII, No. I (1959). "The Morphology of the Ballad Tunes: Variation, Selection, and Continuity," from the Journal of American Folklore, Vol. LXVII, No. 263 (1954). "Toward the Comparative Analysis of British-American Folk-Tunes," from the Journal of American Folklore, Vol. LXXII, No. 284 (1956). "About the Most Favorite British Ballads," from the Journal of the International Folk Music Council, Vol. IX (1957). "Two Reviews: Frank Brown and North Carolina Ballads and Songs," from the Virginia Quarterly Review, the first appearing in Vol. XXIX, No. I (1953), and the second in Vol. XXXIV, No. 3 (1958). "All This for a Song?" from Literary Views: Critical and Historical Essays, a semicentennial publication by Rice University (1962). "Folk-Song in the United States, 1910-1960," was published in the Festscbrift zum 75. Geburtstag von Erich Seemann, from the Jabrbuch für Volksliedforschung (1964). "Cecil Sharp and Folk-Song," from Western Folklore, Vol. XXVII, No. 3 (1968). 


\section{To M. S. B.}

"O what is longer than the way?" 
